\title{
Accumulation characteristics and exploration practices of lithologic reservoirs at eastern margin of the Pre-Caspian Basin
}

\author{
Wang Yankun ${ }^{1, a^{*}}$, Zheng Junzhang ${ }^{1 \mathrm{~b}}$, Wang Zhen ${ }^{1 \mathrm{c}}$, Jin Shutang ${ }^{2 \mathrm{~d}}$, Luo Man ${ }^{1 \mathrm{e}}$ \\ ${ }^{1}$ Research Institute of Petroleum Exploration \& Development, CNPC, Beijing, China \\ ${ }^{2}$ CNPCInternationalAktobe, Kazakhstan \\ awyk_riped@126.com, bzhengjz@cnpcint.com, cwangzhen1@cnpcint.com , d \\ jinshutang@cnpc-amg.kz, ${ }^{\mathrm{l} l u o m a n @ c n p c i n t . c o m ~}$
}

Keywords: Pre-Caspian Basin, Carboniferous, Carbonate, lithologic reservoir, controlling factor; prediction techniques

Abstract: The Carboniferous carbonate rocks at eastern margin of the Pre-Caspian Basin originally depositing at the passive continental margin of Eastern European craton are closely related to accumulation of lithologic reservoirs. Three kinds of lithologic reservoirs, i.e. sedimentary-related, diagenetic-related and unconformable reservoirs, have been found through exploration in recent years. Based on regional structures, single-well sedimentary systems tracts and reservoir diagenesis, it is believed that lithologic reservoirs are controlled by four factors, i.e. tectonic movement, sedimentary environment, diagenesis and systems tract. Seismic attributes and post-stack inversion were used to predict the reservoirs. The predictions were validated by well drilling in the slope zone.

The Pre-Caspian Basin has abundant petroleum resources, 85-90\% of which concentrate in Paleozoic carbonate reservoirs, especially in organic reefs and anticlines, underlying very thick Lower Permian salt domes. At its eastern margin, where favorable geologic setting exists as a result of the uplifting of Uralian orogenic belt at the late stage of the Early Permian Epoch, lithologic reservoirs have been successfully discovered and explored in recent years, and most of them distribute in the west slope in North Tluwa Oilfield. Previous researches often focused on pre-salt seismic data processing and imaging as well as pre-salt structural mapping and trap delineation, which all aimed at structural traps in this basin, e.g. organic reefs, anticlines and fault blocks, but fewer efforts have been made on genesis and prediction techniques of lithologic traps. This paper deals with sedimentary environments, diagenesis and tectonic evolution, so as to find out those controlling factors of lithologic reservoirs .

\section{Geologic setting}

The Pre-Caspian Basin is a Paleozoic-Mesozoic-Cenozoic superimposed basin at the southeast corner of the Eastern European Platform. In accordance with its tectonic features at the end of the Paleozoic Devonian Period, the basin can be divided into a north-northwest fault bench zone, a south uplifted zone, an east uplifted zone and a central depression. The AOI is located in the middle part of the east uplifted zone, $90 \mathrm{~km}$ in east-west direction and $36 \mathrm{~km}$ in north-south direction, covering a total area of $3280 \mathrm{~km}^{2}$ (Fig. 1). Sedimentary formations in the AOI are separated into post-salt and pre-salt formations by more than 20 Lower Permian salt domes, which are 400-3000 m thick and thin in the east and thick in the west. The post-salt part consists of Late Permian to Mesozoic and Cenozoic formations mainly composed of epicontinental clastic rocks, and the pre-salt part consists of Late Paleozoic marine carbonate and clastic rocks. Upper Carboniferous KT-I and Lower Carboniferous KT-II are two major carbonate reservoir beds in the AOI. At eastern margin of the AOI adjacent to the south of Ural fold belt, faults, fractures, unconformable surfaces and "salt windows" are very common as a result of tectonic movement and may act as the pathway for hydrocarbon migration. 


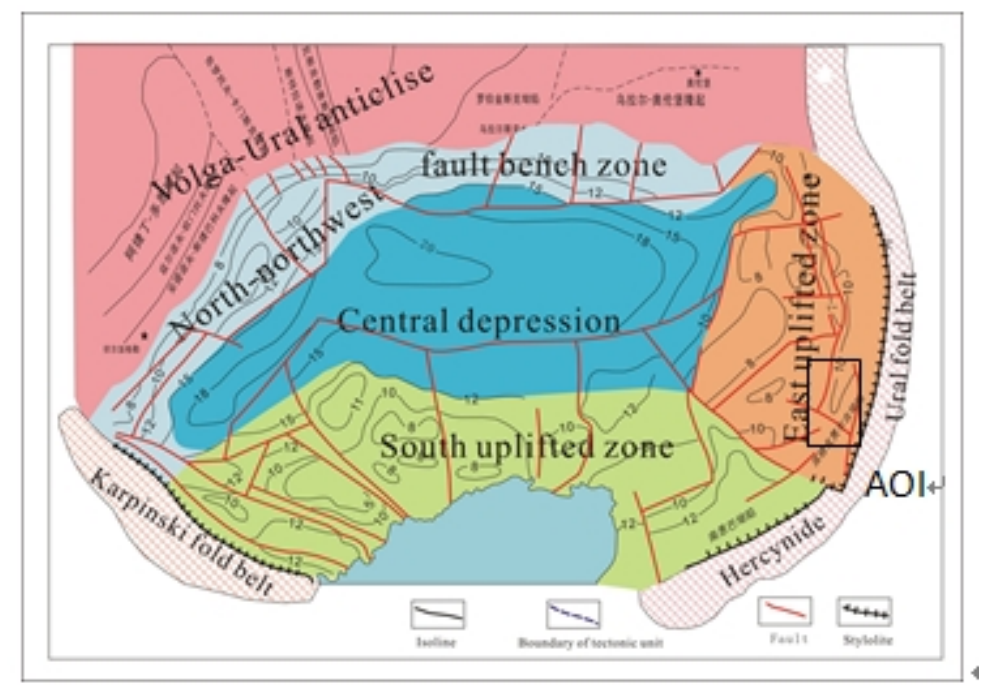

Fig. 1 Structure outline map of the Pre-Caspian Basin

\section{Lithologic reservoir types}

For lithologic reservoirs, hydrocarbons were captured in a lithological three-dimensional unit with variable reservoir properties resulting from stratigraphic truncation, overlap and facies change during sedimentary, diagenetic, tectonic and volcanic processes. In the Pre-Caspian Basin, reservoir beds drilled in each well often could not be correlated and connected laterally. For example, more than a dozen of oil and water systems controlled by lithologies and faults within an area of $300 \mathrm{~km}^{2}$ in North Tluwa Oilfield have been found to exist separately at the top or periclinal position of anticlines or even lower tectonic positions. By genesis-related factors, there may be three types of lithologic reservoirs: (1) sedimentary-related reservoirs with deteriorated properties, i.e. decreased permeability due to increased shale content and fine carbonate particles, in updip direction; (2) diagenetic-related carbonate reservoirs with lenticular geometries, whose properties may be improved locally due to the effect of diagenesis; and (3) unconformable reservoirs related to stratigraphic overlap and unconformable surfaces, which mainly occur above and below the unconformable surfaces between the Carboniferous and Permian Systems and between the Lower Carboniferous Moscovian and Bashkirian Stages, as shown in Fig. 2.

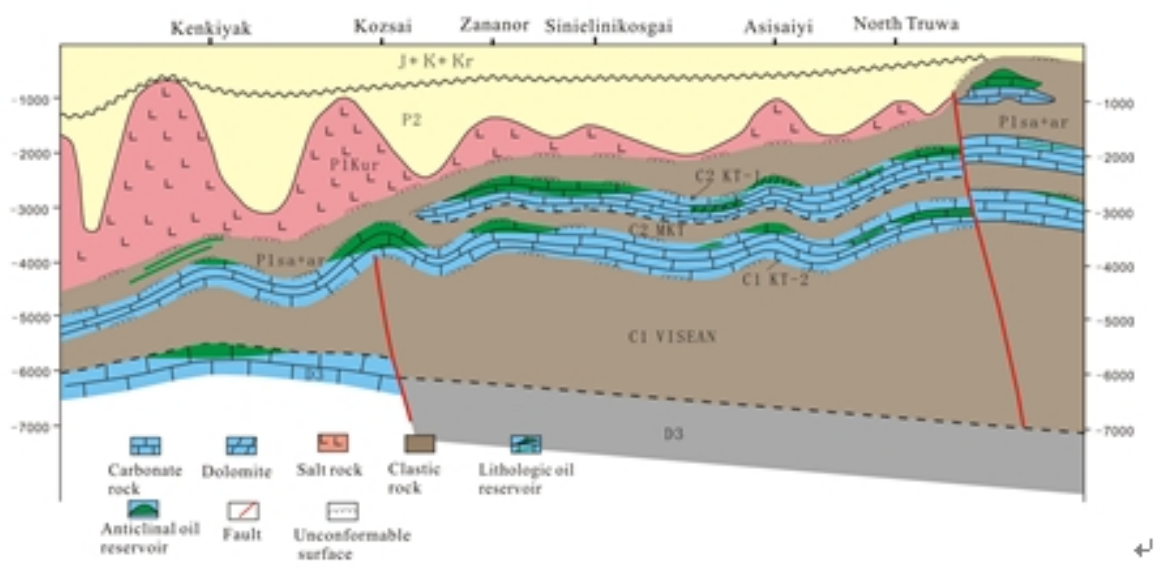

Fig. 2 Hydrocarbon accumulation model for the eastern margin of the Pre-Caspian Basin 


\section{Controlling factors}

\section{Tectonic movement}

Tectonic movement controlled sedimentation as well as hydrocarbon migration and accumulations of lithologic reservoirs. The eastern margin of the Pre-Caspian Basin experienced six stages of structural evolution, i.e. rifting, passive continental margin, rift convergence, fast subsidence, extensive uplifting and denudation, and overall subsidence and salt structure reactivation. The generation of lithologic reservoirs in the AOI was directly related to the stages of passive continental margin and rift convergence.

The stage of passive continental margin corresponds to the period from the Early Devonian Epoch to the Early Carboniferous Epoch, when the whole basin stood at the passive continental margin of Eastern European craton. Thick carbonate rocks deposited at the eastern and southeastern margins of the Pre-Caspian Basin; organic reefs occurred locally. The AOI was structurally high in the west and low in the east, and the dip angle of the slope became obviously smaller as a result of thickened formations in the east, which was favorable for later deposition of shallow plateau facies.

The Carboniferous System consists of two sets of carbonate sedimentary formations $\left(\mathrm{C}_{2} \mathrm{KT}-\mathrm{I}\right.$ and $\left.\mathrm{C}_{1} \mathrm{KT}-\mathrm{II}\right)$ intercalated with a set of clastic formation $\left(\mathrm{C}_{2} \mathrm{MKT}\right)$. As per seismic reflections, KT-I, MKT and KT-II are relatively stable in the east; KT-I and MKT pinch out quickly in the west. Due to the effect of compressional EW stress field during Uralian orogeny at the end of the Carboniferous Period, some areas uplifted to form low-relief anticlines at the east-inclined palaeoslope. The west part of the AOI uplifted and the entire AOI was still east inclined. Marine transgression occurred from east to west. Sea water was relatively shallow with little variation in water depth, which was favorable for biological growth and the generation of organic reefs.

The stage of rift convergence corresponds to the period from the Late Carboniferous Period to the Early Permian Epoch, when concussive tectonic movement in the Late Carboniferous Period resulting from sustained intermittent collision with surrounding plates gave rise to fold belts around this region in the Early Permian Epoch. fossil Ural Ocean closed. the divergent passive continental margin with much rainfall gradually changed into the convergent inland basin with dry climate; as a result, thick salt beds deposited in the basin. After that, pre-salt structures which are high in the east and low in the west became the destination of hydrocarbon migration and lithologic reservoirs mainly concentrated in the slope.

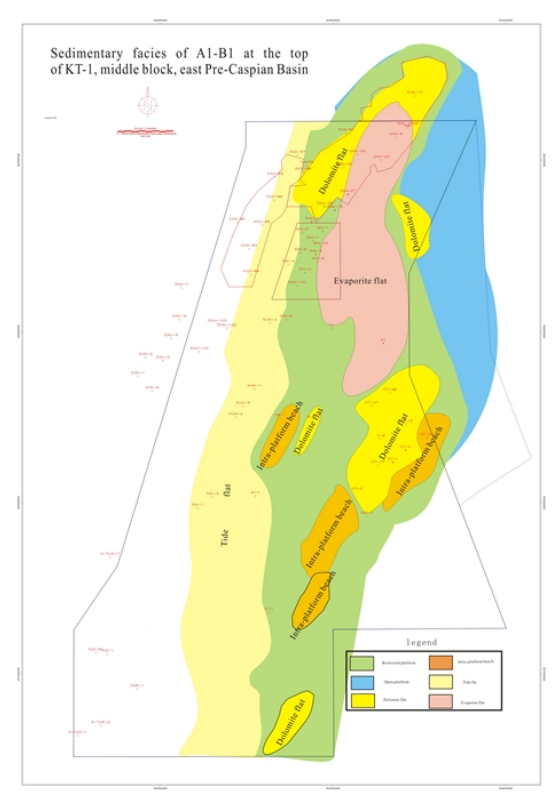

Fig. 3

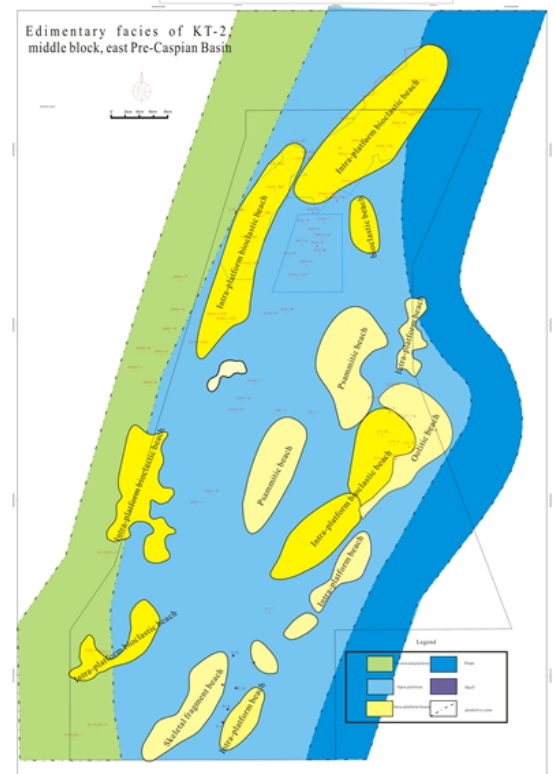

Fig. 4 


\section{Sedimentary environment}

Sedimentary environments decided the distribution of different types of lithologic reservoirs, e.g. bank-type and reef-type. During carbonate deposition in the Carboniferous Period, the AOI in the low-latitude tropic or subtropical zone was in a marine environment where the climate was hot and humid; so it was rich in marine organism. Based on thin-section data, the average content of fossil organism is $37.20 \%$ for KT-I and $59.8 \%$ for KT-II; the average grain content is $54.3 \%$ for KT-I and $77.6 \%$ for KT-II. Grainstone accounts for more than $90 \%$ of Carboniferous carbonate rocks, which indicates a sedimentary facies of organic bank with turbulent water body of high energy. These two sets of carbonate rocks are generally taken as the products of platform facies.

The classification of sedimentary facies was based on Carboniferous petrologic, palaeo-biological and palaeo-tectonic features as well as formation thickness, in which core, thin-section, well logging and well log data were integrated.

KT-I was classified into several sedimentary facies from the bottom up, i.e. shelf, open platform, restricted platform, and evaporite platform. Reservoir beds often exist in restricted platform and evaporite platform facies in the upper part. The restricted platform was deposited with grey to grey-white limestone, brown-grey micrite and argillaceous dolomite with micrite and crystalline powder structures; there is little bioclast. The evaporite platform was covered with high-salinity deposits of evaporite flat and dolomite flat facies (Fig. 3). Grey to grey-white calcareous gypsum rocks and argillaceous gypsum rock occur in belt-shape in the evaporite flat. Dolomite reservoirs have the best petrophysical properties and generally had the highest yields.

KT-II was classified into shelf facies and open-platform facies from the bottom up and reservoir beds generally occur in the open-platform facies which could be subdivided into interbank sea, intra-platform beach and platform flat. Intra-platform beaches in the AOI include bioclastic beach, skeletal fragment beach, psammitic beach, oolitic beach, etc. (Fig. 4). The psammitic beach was mainly deposited with micrite calcarenite rich in intercrystalline and intergranular pores. The oolitic beach was mainly deposited with sparry oolitic limestone rich in intra-oolith and oolimold pores. The bioclastic beach was deposited with thin sparry bioclastic limestone and micrite bioclastic limestone with many intergranular and intragranular pores. These three kinds of beach-type particles were intensively abraded and packed. Oil and gas may be captured in those beach-type reservoir rocks with good petrophysical properties.

\section{Diagenesis}

Diagenesis controlled the size of reservoir space and the abundance and volume of hydrocarbon resources in the Carboniferous carbonate reservoirs. As per thin-section and SEM observations and other research findings, the Carboniferous carbonate rocks experienced six types of diagenesis, i.e. chemical erosion, dolomitization, fracturing, compaction, cementation and packing action. The former three types improved the porosity and permeability, while the later three types impaired the porosity and permeability. Destructive diagenesis prevailed over constructive diagenesis in those tight zones and constructive diagenesis prevailed over destructive diagenesis in those reservoir beds. In North Tluwa Oilfield, average reservoir thickness coefficient is $8.16 \%$ for KT-I and $10.64 \%$ for KT-II, which means that most hole-sections are tight and reservoir beds are relatively thin.

KT-I carbonate rocks experienced evaporite dolomitization and backflow penetrative dolomitization. Dolomites have hypidiomorphic to xenomorphic crystalline-powder to aplitic textures generally associated with evaporite minerals or rocks. Shale content is usually high. Secondary pores, e.g. intercrystalline (dissolved) pores, dissolved pores (cavities) and fractures, compose almost all the reservoir space in dolomite reservoirs, as shown in Fig. 5. Surface porosities of visceral foramina and intercrystalline dissolved pores are $30.91 \%$ and $28.4 \%$, respectively. For dolomite reservoirs, the porosity may reach $21.3 \%$ and well production rate is high. This kind of dolomitized lithologic reservoirs generally exist in KT-I and has a lenticular geometry. 


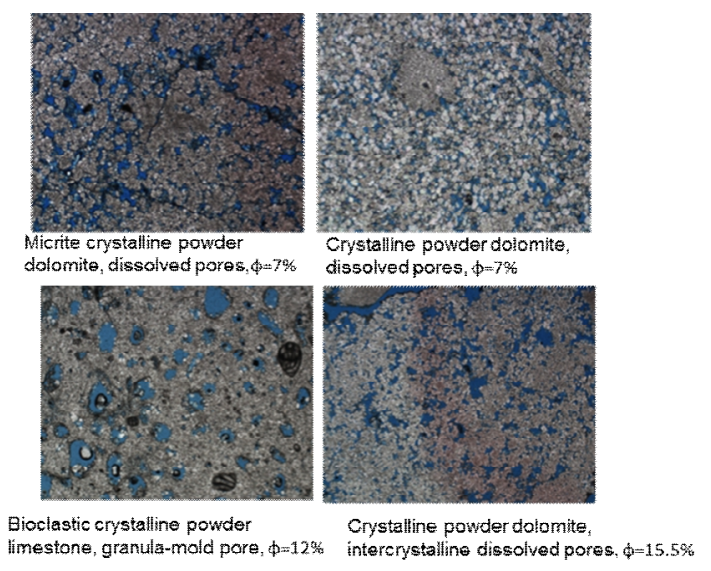

Fig. 5 Reservoir space in KT-I

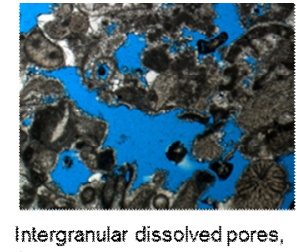

Intergranular dissolved pores, $010.3 \%$

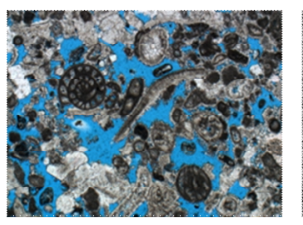

Organic visceral foramina, intergranular pores

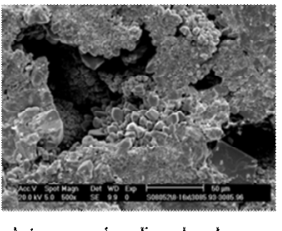

Intergranuar dissolved pores $500 x$

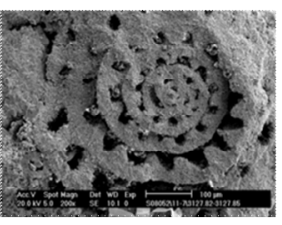

Organic visceral foramina, $200 x$

Fig. 6 Reservoir space in KT-II

In accordance with thin-section observations, chemical erosion of Carboniferous carbonate rocks in the middle block could be classified into contemporaneous-penecontemporaneous erosion, hypergenic erosion and burial erosion. Chemical erosion mainly affected KT-II top and KT-I top around North Tluwa Oilfield; the southern and western parts of the AOI did not undergo intense erosion process. Surface porosity of intergranular and intragranular dissolved pores, moldic pores and intercrystalline dissolved pores resulting from chemical erosion generally ranges between $10 \%$ and $35 \%$. Carboniferous reservoir beds are rich in dissolved pores, which constitute a considerable part of reservoir space in lenticular reservoir rocks of beach facies, as shown in Fig. 6. This kind of lenticular reservoir beds occur frequently in vertical direction, but the single-layer thickness is small. Contemporaneous and penecontemporaneous chemical erosion generated a large number of pores, most of which were cemented by sparry calcite and only a few were preserved. Surface porosities of intergranular pores and visceral foramina are $55.47 \%$ and $27.2 \%$, respectively; the porosity is $17.5 \%$. Intercrystalline (dissolved) pores are underdeveloped and the surface porosity is only $2.11 \%$, which demonstrates the controlling effect of diagenesis on the volume of sedimentary-related lithologic reservoirs.

Most natural fractures are stylolites, which generally have been filled. Structural and dissolved fractures may also be observed, but high-angle structural fractures are rare. Low-angle fractures and bedding fissures are relatively common and may act as the pathway for hydrocarbon migration.

\section{Transgressive systems tract and highstand systems tract}

Transgressive systems tract and highstand systems tract dominated barrier layers. Six supersequence (order-II) boundaries (entitled SB0, SB1, SB2, SB3, SB4 and SB5 from the bottom up) and 2 maximum marine flooding surfaces ( $\mathrm{Sq} 1$ and $\mathrm{Sq} 2$ from the bottom up) were identified for the Carboniferous System in the AOI, which was therefore partitioned into 5 supersequences entitled Ss1, $\mathrm{Ss} 2, \mathrm{Ss} 3, \mathrm{Ss} 4$ and Ss5 and 11 order-III sequences. Each sequence is the product of a sedimentary cycle, while a formation or member may usually be classified based on lithologic variation. As per the principles of sequence stratigraphy, KT-II formed in the process of relative seal-level rise, when two major transgression and regression events occurred and correspond to the sequences of Ss1 and Ss2, which are shown as multiple cycles of repeated subfacies in the open platform. KT-I was generated during marine regression, when two major transgression and regression events also occurred and correspond to Ss4 and Ss5. Due to sea-level drop, open platforms alternate with restricted platforms, giving rise to multiple cycles shallowing upward. Evaporate platform facies occurs at the top of the sequence. Ss3 formed in the process of a large-scale transgression when the base level rose. It has the most complete fabric and was deposited with thick clastic rocks. In summary, the zones of interest experienced two large-scale transgressions and regressions, which correspond well with global base-level change.

Each supersequence consists of a transgression systems tract and a highstand systems tract. It is 
difficult to identify the lowstand systems tract due to its short lifetime. In each supersequence, lithologies change from coarse grains to fine grains and finally to coarse grains. Oil layers mainly exist in Ss2 and Ss5.

Ss2 is $170 \mathrm{~m}$ thick and at the upper part of KT-II. The transgression systems tract is composed of intra-platform and bioclastic beaches of open-platform facies with sparry bioclastic limestone, algal limestone and sparry grainstone. The sea level stopped to rise in this period and more sediments were deliverable. Sea water became shallow; some intra-platform patch reefs composed of algal-lump limestone, argilliferous micrite and sparry algal-lump limestone came into being. Arene content increased for intra-platform beaches. The transgression systems tract had sufficient sedimentary sources and was deposited with extensive bioclastic limestone rich in primary pores. This kind of limestone was apt to be altered at the late stage to generate secondary pores. So, the porosity might be further improved. Argillaceous limestone formed during water body deepening in the east and then was uplifted due to late tectonic inversion. It may act as the barrier to block off hydrocarbons within the lithologic reservoir. Overlying thick mudstone or argillaceous limestone forming in the process of transgression may also act as the barrier. Hydrocarbons may migrate along unconformable surfaces and permeable formations.

Ss5 is $140 \mathrm{~m}$ thick and at the upper part of KT-I. The transgression systems tract is composed of deposits of bioclastic beach microfacies in intra-platform beach subfacies, restricted platform facies. The marine flooding surface was deposited with micrite fusulina limestone of bioclastic beach microfacies in intra-platform beach subfacies, restricted platform facies. The highstand systems tract is at the transition zone from restricted platform to evaporite platform and was deposited with thick gypsum rocks; dolomite reservoirs (i.e. KT-I oil layers) are likely to occur within the restricted platform. Fine-grained sediments forming during the highstand systems tract may prevent hydrocarbons from escaping from lithologic reservoirs. On the other hand, dolomite may be altered by secondary karsification to improve its reservoir properties due to more fractures generated by increased formation pressure. Anhydrite and variegated mudstone at the top boundary of the sequence may act as regional overburden.

\section{Application and results}

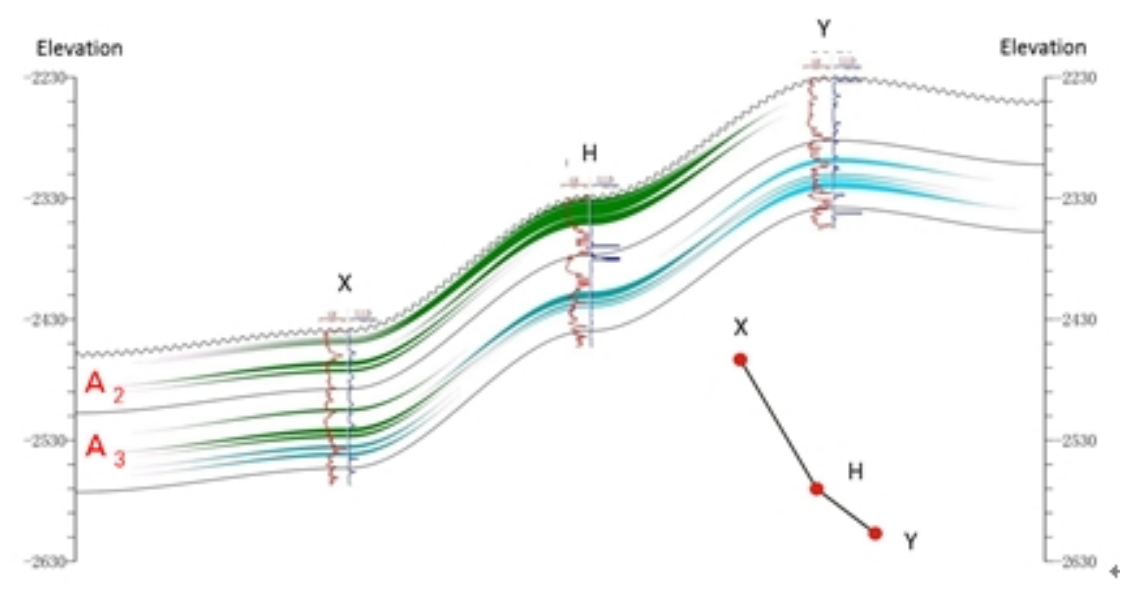

Fig. 7 Reservoir section across Wells $\mathbf{X}, \mathbf{H}$ and $\mathbf{Y}$

We integrated some seismic attributes, e.g. RMS amplitude, thin-bed indicator and sweetness, and geostatistical inversion and predicted 27 sweet spots of $100 \mathrm{~km} 2$ for KT-I and KT-II in the west slope of North Tluwa Oilfield in the middle block, the Pre-Caspian Basin. As per seismic predictions as well as structures, oil testing, palaeostructure restoration and reservoir-seal assemblages, 12 wells were deployed outside the oil-water contact of the oilfield from 2011 to 2014; 6 wells yielded commercial oil 
flow and 3 wells yielded oil and water. Proved oil reserves in place exceeded 10 million tons. For example, Well Y yielded commercial oil flow from Lower Carboniferous KT-II in 2011 and the oil layer is $100 \mathrm{~m}$ lower than the oil-water contact in the oilfield. In the same year, Well CT-48 drilled in the northwest slope yielded commercial oil flow from KT-I and the oil layer is $40 \mathrm{~m}$ lower than the oil-water contact. From 2012 to 2014, Wells H, H1 and X (Fig. 7) yielded commercial oil flow from oil layers 100, 200 and $280 \mathrm{~m}$ lower than the oil-water contact, respectively. Well X yielded both oil and water. Successful exploration of Carboniferous carbonate reservoirs at the eastern margin of the basin is a breakthrough after the exploration of structural reservoirs for a century and also demonstrates the credibility of geophysical prospecting techniques in carbonate reservoir exploration in this region.

\section{Conclusions}

(1) By controlling factors, lithologic reservoirs discovered at the eastern margin of the Pre-Caspian Basin can be classified into three types, i.e. sedimentary-related, diagenetic-related and unconformable reservoirs.

(2) Tectonic movement controlled sedimentation and hydrocarbon migration in the AOI. Sedimentary environments dominated the distribution of high-grade reservoirs. Diagenesis dominated reservoir properties and the volume of reserves. Transgressive and highstand systems tracts dominated reservoir-seal assemblages.

(3) KT-I reservoir rocks mainly consist of dolomitic limestone, bioclastic limestone and crystalline powder dolomite. Hydrocarbons may migrate laterally along unconformable surfaces and permeable formations and then be blocked off by impervious rocks in updip direction. KT-II mainly consists of sparry algal limestone and sparry foraminiferal limestone slightly dolomitized. Thick mudstone or argillaceous limestone forming in the process of transgression may also act as the barrier. Sealing performance of these lithologic barriers is crucial to hydrocarbon accumulation.

\section{References}

[1] Liu Luofu, Zhu Yixiu, Xiong Zhengxiang, et al. Characteristics and evolution of lithofacies plaeogeography in Pre-Caspian Basin. Journal of Palaeogeography, 2003, 5(3): 279-289.

[2] Wang Tao. Symposium of Sino-Russia petroleum geology seminar. Beijing: Petroleum Industry Press, 2004.

[3] Geogory FU. Petroleum geology and resource of the North Caspian Basin, Kazakhstan and Russia. USGSBULL. 2001, (2201-B): 29-40

[4] Xu Huaida, Zhao Zhengzhang, Fan Tailiang, et al. From seismostratigraphy to sequence stratigraphy. Beijing: Petroleum Industry Press, 1997.

[5] Xu Huaida, Wang Shifeng, Chen Kaiyuan. Bases of seismostratigraphical interpretation. Beijing: China University of Geosciences Press, 1990.

[6] Liu Luofu, Guo Yongqiang, Zhu Yixiu. Reservoir characteristics and oil-hearing characters of the carbonate reservoir beds in the pre-salt of Pre-Caspian Basin. Journal of Xian Shiyou University, 2007, 22(1): 53-58.

[7] Jin Zhijun, Wang Jun, Zhang Shenggen, et al. Main factors controlling hydrocarbon reservoirs and exploration directions in the pre-salt sequence in Pre-Caspian Basin. Petroleum Geology \& Experiment, 2007, 29(2): 111-115.

[8] Jin Zhijun, Wang Jun, Zhang Shenggen, et al. Main factors controlling hydrocarbon reservoirs and exploration directions in the pre-salt sequence in Pre-Caspian Basin. Petroleum Geology \& Experiment, 2007, 29(2): 111-115. 